\title{
COMPARISON OF ENAMELED STEEL SUBSTRATE PROPERTIES FOR THICK FILM USE
}

\author{
S. J. STEIN, C. HUANG and A. S. GELB \\ Electro-Science Laboratories, Inc., Pennsauken, N.J.
}

(Received June 11, 1979)

\begin{abstract}
Porcelain enameled steels have had a long history of industrial, structural and related applications. Recent interest in such materials has centered on electrical uses as a substrate for hybrid circuits, additive printed wiring, and packaging. A study of some of the critical properties of available enameled steels was undertaken.

Five types of enameled steel substrates from three manufacturers were tested. The electrical properties studied included dielectric constant, dissipation factor, voltage breakdown, surface and bulk insulation resistance. The effect of humidity on the insulation resistance of the enamel coatings themselves was compared. The influence of the thermal conductivity of the substrates was also examined.

The properties of a thick film resistor system was determined on the various enamel steel substrates. The properties tested included resistivity and TCR firing sensitivity.

The effect of the type of substrate on the properties of a selection of thick film conductors was determined. Conductivity and gold and aluminum wire bond strength were compared on the various substrates.

The dielectric properties of a multilayer/crossover dielectric thick film material were compared among $96 \%$ alumina, soda-lime glass and the various enameled steel substrates.

Many individual differences between the enameled steel substrates were found. However, all of the substrates could be utilized to produce satisfactory thick film circuits when the proper choice of thick film materials was made.

Continuing changes, improvements and additional sources of supply are expected to overcome some of the present shortcomings. These should enhance the use of such substrates for large area uses and lower cost applications.
\end{abstract}

\section{INTRODUCTION}

The art and science of fusing glasses (now known as porcelain enamels or simply enamels) to metal surfaces dates back to the ancient Egyptians. The earliest use was for jewelry where the enamel was fused to gold. By the middle ages, the range of metals capable of being glass-coated progressed from the noble to the base; gold followed by silver, bronze, copper and, in the early 1800's, cast iron. Enamel was first applied to sheet iron and steel in Austria and Germany shortly after 1850 . In the 1900's, the enamel industry grew rapidly, with many new applications such as appliances, hot water heaters and architectural panels. Now in the 1970's, this ancient art is finding new application in one of our newest industries-electronics.

The use of a variety of porcelain enameled steel substrates for thick film circuits will be discussed in this paper. A short review of the technology employed in the manufacture of these substrates is useful, in order to improve our understanding of the results of coating them with thick film materials.
The enamels used consist of an acidic refractory material such as quartz, feldspar or clay reacted with a basic flux such as borax, soda ash, cryolite or fluorspar to form glass. The melted glass is fritted and ball milled in water. Depending on the ultimate function of the enamel, various additives may be used such as pigments, opacifiers, clays or other materials to serve as defloculants and floatation agents, which help suspend the enamel particles in an aqueous solution. A small percentage of cobalt oxide $(<.5 \%)$ is sometimes used for improved adhesion to steel.

The enamel so formed, if destined for substrate use, must have a melting temperature high enough to allow for firing of thick film materials and low enough to minimize oxidation and warping of the steel. Since glass is relatively weak in tensile strength and almost always fails in tension, the enamel is designed to have a lower thermal expansion characteristic than the metal, in order to keep the glass in compression. The lower expansion of the enamels as compared to iron holds for temperatures below about $500^{\circ} \mathrm{C}$. Above $500^{\circ} \mathrm{C}$, the expansion of the 


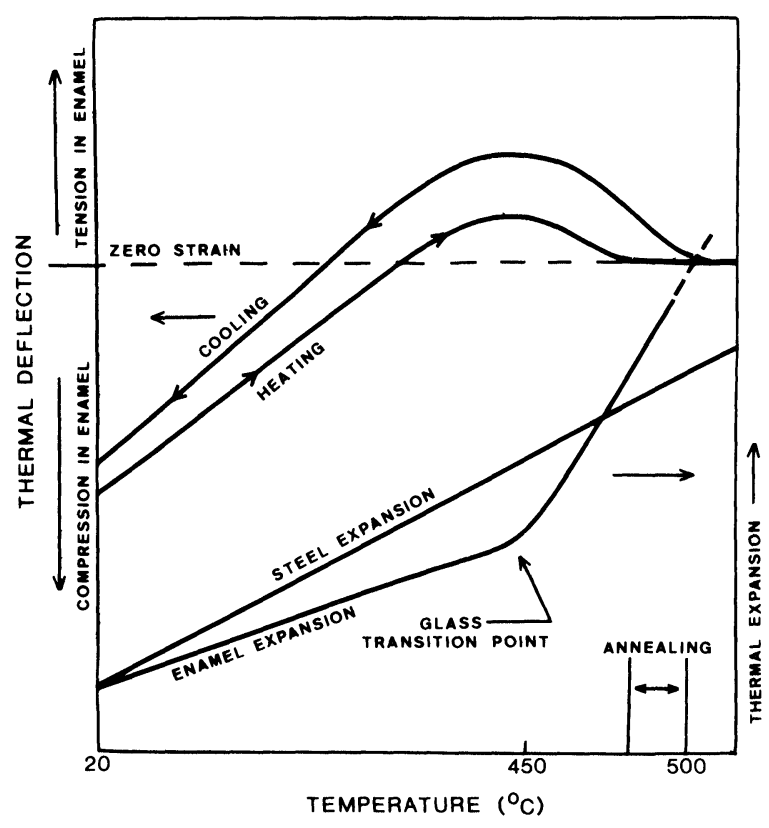

FIGURE 1 Thermal deflection and thermal expansion showing the change from tensile to compressive stress in the enamel during cooling.

enamels increases to a level greater than that of the steel. During initial firing of the enamels and also during the firing and subsequent cooling of thick film materials, the enamel undergoes an initial tensile stress, and finally goes into compression at below about $300^{\circ} \mathrm{C}$. The faster the cooling rate used during firing of thick films, the greater will be the residual degree of compression in the enamel. (See Figure 1).
For electronic grade substrates, extra low carbon steel $(<0.003 \% \mathrm{C})$ has been found to minimize surface defects. Typically, the steel is chemically cleaned, acid pickled to remove surface oxides, and plated with nickel in an electroless nickel plating solution. ${ }^{1}$

The glass powder is applied to the steel by either:

1) Dipping, slushing or spraying of a water-based slurry or slip.

2) Electrophoretic deposition, which is similar to dipping with an applied electric field. The glass is essentially plated from the slip and coverage of the metal is very uniform.

3) Electrostatic spraying, in which the powder is sprayed dry with high voltage charges of opposing polarity applied to the steel and the powder. This process is also considered to produce uniform coatings. ${ }^{2}$

After drying (for those powders applied wet), the enamels are typically fired for 1 to 3 minutes at $800^{\circ} \mathrm{C}$ to $890^{\circ} \mathrm{C}$ peak temperatures in a conveyor furnace.

This paper surveys the critical properties of the porcelain enamels and their effect on the properties of thick film materials.

\section{PROPERTIES OF PORCELAIN ENAMELS AND PORCELAIN ENAMELED STEEL SUBSTRATES}

Several properties are highly important in determining the suitability of potential materials for thick film substrate use. Among these properties

TABLE I

Typical properties of thick film substrate materials

\begin{tabular}{|c|c|c|c|c|c|}
\hline & $\begin{array}{l}\text { G-10 Epoxy } \\
\text { Laminate }\end{array}$ & $\begin{array}{l}\text { Soda-Lime } \\
\text { Glass }\end{array}$ & $\begin{array}{l}\text { Enameled } \\
\text { Steel }\end{array}$ & $\begin{array}{l}96 \% \\
\text { Alumina }\end{array}$ & $\begin{array}{l}99.5 \% \\
\text { Beryllia }\end{array}$ \\
\hline Typical Thkn.(mm) & 1.50 & 1.25 & 1.13 & 0.63 & 0.63 \\
\hline $\begin{array}{l}\text { Sheet Dens. }\left(\mathrm{g} / \mathrm{cm}^{2}\right. \\
\text { per } \mathrm{mm} \text { of Thickness) }\end{array}$ & 0.19 & 0.25 & 0.71 & 0.37 & 0.29 \\
\hline Tens. Str. $\left(\mathrm{kg} / \mathrm{cm}^{2}\right)$ & 2,500 & 800 & 3,200 & 1,800 & 1,600 \\
\hline $\begin{array}{l}\text { Coef. of Thermal } \\
\text { Expansion }\left(10^{-7} /{ }^{\circ} \mathrm{C}\right)\end{array}$ & $110-120$ & $85-90$ & $60-70$ & $64-70$ & $68-75$ \\
\hline $\begin{array}{l}\text { Thermal Conductivity } \\
\left(\mathrm{cal} . \mathrm{cm} / \mathrm{sec} . \mathrm{cm}^{2}{ }^{\circ} \mathrm{C}\right) \\
\text { at } 200^{\circ} \mathrm{C}\end{array}$ & 0.0007 & 0.002 & $\begin{array}{l}\text { Glass } 0.002 \\
\text { Steel } 0.13\end{array}$ & 0.05 & 0.35 \\
\hline $\begin{array}{l}\text { Maximum Processing } \\
\text { Temperature }\left({ }^{\circ} \mathrm{C}\right)\end{array}$ & 200 & 625 & 675 & 1550 & 1500 \\
\hline
\end{tabular}


are weight per unit area, strength, coefficient of thermal expansion and maximum processing temperature. Table I gives typical values of these properties as obtained from the literature for materials which are commonly used as thick film substrates. ${ }^{3,4,5}$

Enameled steel is significantly denser than the other substrate materials, and it also is stronger. This, combined with the relative ease of steel formability, enable it to be used as a structural component, in addition to being used as a carrier of electronic circuitry, in some applications. The high weight factor is not significant in many industrial and consumer applications. The composite coefficient of thermal expansion poses no unusual problems for thick film materials since it is near the value for alumina, the most commonly used substrate material.

The dissipation of heat from circuitry is strongly affected by the substrate thermal conductivity. ${ }^{6}$ This paper will show data on the temperature of resistors on a variety of substrates.

The maximum processing temperature is important since thick film resistor stability is often a function of the maximum firing temperature. By this criterion, resistors fired on enameled steel should be intermediate in stability between those deposited on plastics and ceramics.

The manufacturers of the substrates used in this investigation are Alphametals, Advanced Technology Division, Newark, N.J.; Erie Ceramic Arts Company, Erie, Pa.; and General Electric Company, Mattoon, Ill. The Erie substrates tested were $25 \mathrm{~mm}$ square, the Alphamet ${ }^{\mathrm{TM}}$ substrates were $25 \mathrm{~mm} \times 31 \mathrm{~mm}$, and the General Electric substrates were $50 \mathrm{~mm} \times 50 \mathrm{~mm}$.

Chemical composition of the enamel obviously plays an important role in determining physical and electrical properties. ${ }^{7}$ As described by their manufacturers, Alphamet ${ }^{\text {TM }}$ and General Electric substrates are low in sodium ions as is Erie 3723. The 3677 substrates, manufactured earlier by Erie, contained higher sodium levels. The literature ${ }^{3}$ shows for Alphamet ${ }^{\mathrm{TM}} 120$ ppm lithium, $2.98 \%$ sodium and $4.13 \%$ potassium. Erie 3707 (reported by Erie to be similar in composition to their 3723) contained $80 \mathrm{ppm}$ lithium, $5.17 \%$ sodium and $0.21 \%$ potassium. The Alphamet ${ }^{\mathrm{TM}}$ and the General Electric enamels are applied by an electrophoretic process while the Erie enamel is sprayed on. All are apparently single step processes. In some instances, an intermediate ground coating may be applied before coating with the final enamel layer.

Figure 2 illustrates an Alphamet ${ }^{\mathrm{TM}}$, a General Electric, and an Erie substrate printed with a test pattern. One corner of the enamel has been removed

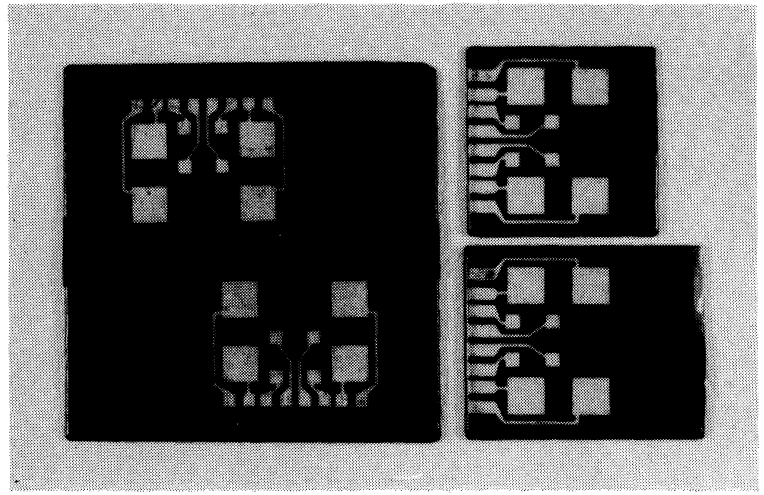

FIGURE 2 GE (left), Erie (top right), Alphamet ${ }^{T M}$ (bottom right) substrates.

to provide a place to make electrical contact to the underlying steel. The conductor, and all other thick film materials in this paper, unless otherwise noted, were fired at $625^{\circ} \mathrm{C}$ in a belt furnace. The total firing cycle is 45 minutes long with 10 minutes to 12 minutes at peak temperature. Table II shows a number of dielectric properties of the porcelain enamels. These measurements were obtained by making contact to the steel substrate and to the thick film conductor. Tests were made with four different types of conductors. As indicated in the table, two types of Alphamet ${ }^{\mathrm{TM}}$ substrates, differing only in steel thickness, two types of Erie substrates, 3677 (high sodium enamel) and 3723 (lower sodium), and one type of General Electric substrate were investigated. Measured in the way described, the dielectric constants of the enamels range from 8 to 22. If equal weight is given to the dielectric constant obtained with each conductor, both types of Alphamet ${ }^{\mathrm{TM}}$ and both types of Erie substrates produce approximately the same average dielectric constant. The General Electric substrates give substantially lower dielectric constant values than the other substrates.

Breakdown voltages, given as volts per $\mu \mathrm{m}$ of enamel thickness, are highest for General Electric substrates, next highest for the Alphamet ${ }^{\mathrm{TM}}$ substrates, and lowest for the Erie substrates. Much of this lower value for the Erie substrates may be due to poor coverage of the edges on the Erie substrates. At breakdown, arcing usually occurs between the contact and the edge of the substrate. The good results on the General Electric substrates may be partially attributable to their larger size, since the test pattern (Figure 2) is well-removed from the substrate edges. 
TABLE II

Electrical properties of porcelain enamel coatings on steel

\begin{tabular}{|c|c|c|c|c|c|c|c|}
\hline Substrate & Conductor & $\begin{array}{l}\text { Enamel } \\
\text { Thickn. } \\
(\mu \mathrm{m})\end{array}$ & $\begin{array}{l}\text { Diel. } \\
\text { Const. } \\
\text { K }\end{array}$ & $\mathrm{DF}(\%)$ & $\begin{array}{l}\text { Volt. } \\
\text { Break- } \\
\text { down } \\
(\mathrm{V} / \mu \mathrm{m})\end{array}$ & $\begin{array}{l}\text { Surf. } \\
\text { Ins. } \\
\text { Res. } \\
\left(10^{10} \Omega\right)\end{array}$ & $\begin{array}{l}\text { Bulk } \\
\text { Ins. } \\
\text { Res. } \\
\left(10^{10} \Omega\right)\end{array}$ \\
\hline $\begin{array}{l}\text { Alphamet } \\
\text { Thick }\end{array}$ & $\begin{array}{l}\text { 8835-1B, Au } \\
5836, \mathrm{Pt}-\mathrm{Au} \\
\text { 9694, Pd-Ag } \\
\text { 9996-A, Ag }\end{array}$ & $\begin{array}{l}150 \\
150 \\
150 \\
150\end{array}$ & $\begin{array}{l}22 \\
20 \\
10 \\
17\end{array}$ & $\begin{array}{l}0.64 \\
0.32 \\
0.00 \\
0.18\end{array}$ & $\begin{array}{l}15.3 \\
15.3 \\
12.7 \\
14.6\end{array}$ & $\begin{array}{r}1.8 \\
1.4 \\
17.4 \\
1.5\end{array}$ & $\begin{array}{l}0.7 \\
0.7 \\
5.4 \\
0.9\end{array}$ \\
\hline $\begin{array}{l}\text { Alphamet } \\
\text { Thin }\end{array}$ & $\begin{array}{l}\text { 8835-1B, Au } \\
\text { 5836, Pt-Au } \\
9694, \mathrm{Pd}-\mathrm{Ag} \\
\text { 9996-A, Ag }\end{array}$ & $\begin{array}{l}150 \\
150 \\
150 \\
150\end{array}$ & $\begin{array}{r}22 \\
18 \\
9 \\
19\end{array}$ & $\begin{array}{l}0.50 \\
0.17 \\
0.00 \\
0.61\end{array}$ & $\begin{array}{r}8.0 \\
8.0 \\
8.7 \\
10.0\end{array}$ & $\begin{array}{r}0.5 \\
4.3 \\
11.7 \\
4.5\end{array}$ & $\begin{array}{l}0.3 \\
1.1 \\
4.7 \\
4.0\end{array}$ \\
\hline Erie \#3677 & $\begin{array}{l}\text { 8835-1B, } \mathrm{Au} \\
5836, \mathrm{Pt}-\mathrm{Au} \\
\text { 9694, Pd-Ag } \\
\text { 9996-A, Ag }\end{array}$ & $\begin{array}{l}130 \\
130 \\
130 \\
130\end{array}$ & $\begin{array}{l}19 \\
15 \\
15 \\
16\end{array}$ & $\begin{array}{l}0.38 \\
0.15 \\
0.12 \\
0.47\end{array}$ & $\begin{array}{l}3.8 \\
3.5 \\
5.4 \\
6.9\end{array}$ & $\begin{array}{l}3.9 \\
3.9 \\
6.8 \\
1.4\end{array}$ & $\begin{array}{l}0.9 \\
1.4 \\
3.4 \\
1.2\end{array}$ \\
\hline Erie \#3723 & $\begin{array}{l}\text { 8835-1B, } \mathrm{Au} \\
5836, \mathrm{Pt}-\mathrm{Au} \\
\text { 9694, Pd-Ag } \\
\text { 9996-A, Ag }\end{array}$ & $\begin{array}{l}140 \\
140 \\
140 \\
140\end{array}$ & $\begin{array}{l}15 \\
16 \\
15 \\
19\end{array}$ & $\begin{array}{l}0.10 \\
0.17 \\
0.00 \\
0.35\end{array}$ & $\begin{array}{l}3.6 \\
4.3 \\
2.2 \\
2.5\end{array}$ & $\begin{array}{l}1.3 \\
0.007 \\
0.001 \\
\text { Short }\end{array}$ & $\begin{array}{l}0.7 \\
0.1 \\
\text { Short } \\
0.001\end{array}$ \\
\hline $\begin{array}{l}\text { General } \\
\text { Electric }\end{array}$ & $\begin{array}{l}8835-1 \mathrm{~B}, \mathrm{Au} \\
5836, \mathrm{Pt}-\mathrm{Au} \\
9694, \mathrm{Pd}-\mathrm{Ag} \\
9996-\mathrm{A}, \mathrm{Ag}\end{array}$ & $\begin{array}{l}140 \\
140 \\
140 \\
140\end{array}$ & $\begin{array}{l}7 \\
8 \\
8 \\
8\end{array}$ & $\begin{array}{l}0.50 \\
0.50 \\
0.50 \\
0.50\end{array}$ & $\begin{array}{l}16.3 \\
24.4 \\
26.1 \\
27.1\end{array}$ & $\begin{array}{l}240.0 \\
210.0 \\
230.0 \\
250.0\end{array}$ & $\begin{array}{l}70.0 \\
70.0 \\
70.0 \\
70.0\end{array}$ \\
\hline
\end{tabular}

\section{NOTES}

1. Alphamet ${ }^{\mathrm{TM}}$ thick substrates were enamel coated on both sides. Overall thickness approx. $2.5 \mathrm{~mm}$.

2. Alphamet ${ }^{\mathrm{TM}}$ thin substrates were enamel coated on both sides. Overall thickness approx. $1.0 \mathrm{~mm}$.

3. Both types of Erie substrates were enamel coated on one side with ceramic spray on the other side. Overall thickness approx. $1.125 \mathrm{~mm}$.

4. General Electric substrates were enamel coated on both sides.

Overall thickness approx. $1.0 \mathrm{~mm}$.

5. Surface insulation resistance measured through gap of $0.75 \mathrm{~mm}$ across, $5 \mathrm{~mm}$ wide.

6. Bulk insulation resistance measured through a $36 \mathrm{~mm}^{2}$ area.

7. Enamel thickness measured using Elcometer magnetic flux thickness gauge.

The General Electric substrates have much higher room temperature surface and bulk resistivities than the Alphamet ${ }^{\mathrm{TM}}$ and Erie substrates. On the Alphamet ${ }^{\mathrm{TM}}$ and Erie substrates (except for Erie 3723, which has problems with shorts and will be discussed below) the Pd-Ag conductor gives the highest surface and bulk resistivity values, although still well below the values observed on the General Electric substrates.

As just discussed, shorts from the thick film conductor to the steel core of the substrate present occasional problems. Conductor overlapping the edge of the substrate usually leads to a short circuit, particularly with the Erie 3723 substrates tested. All of the substrates have occasional minute surface depressions forming thin areas, some of which penetrate to the steel, resulting in pinholes. In addition, surfaces are not smooth and all show an "orange peel" appearance to some degree, especially the General Electric and Erie 3677. Substrate manufacturers must further improve their processes and/or their quality control to minimize these defects for this technology to develop widespread application.

Figure 3 illustrates the bulk resistance of the enamels measured at $150^{\circ} \mathrm{C}$, After each measurement, the plates are held at $150^{\circ} \mathrm{C}$ with 100 volts d.c. applied between the $5 \mathrm{~mm} \times 5 \mathrm{~mm}$ conductive pads and the steel core. Erie 3677 have a much lower elevated temperature bulk resistance than any of the other substrates tested. Since the literature ${ }^{8}$ 


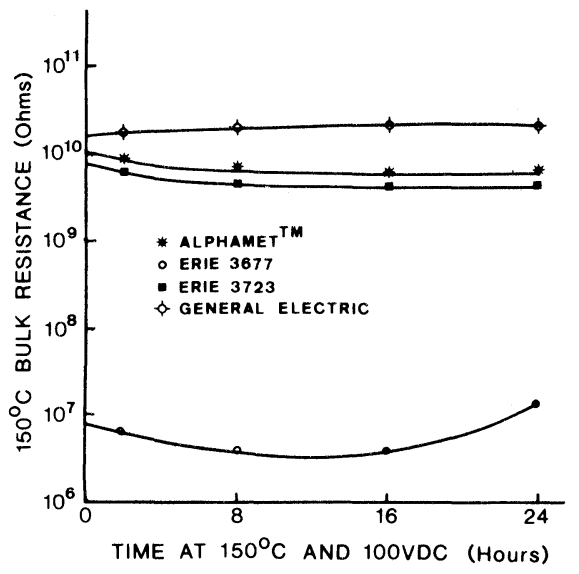

FIGURE 3 Elevated temperature resistance of various enameled steel substrates.

shows that conduction in porcelain enamels is caused by sodium ion movement, it is likely that this lower resistance is due to the higher concentration and higher mobility of the alkali metal ions in that particular composition.

In order to determine the heat dissipating characteristics of the various porcelain enamel substrates, ESL \#3114 (10 k ohm/sq) resistor paste was printed and fired onto ESL \#9694 Pd-Ag terminations. $50 \mu \mathrm{m}$ thermocouples were then cemented on the resistor and on the underside of the substrate opposite the resistor. Power was applied to a $2.5 \mathrm{~mm} \times 2.5 \mathrm{~mm}$ resistor on each type of substrate. Ten volt increments were used, holding at each voltage step for two minutes. The test pattern used is illustrated in Figure 4. The Alphamet ${ }^{\mathrm{TM}}$ substrates used in this and the subsequent tests reported in this work were the "thin" Alphamet ${ }^{\mathrm{T} M}$ substrates described in Table II. Figure 5 shows the temperatures reached for the resistors on the various substrates for each power level. The temperature of each resistor is shown (top) as well as the temperature of the under-

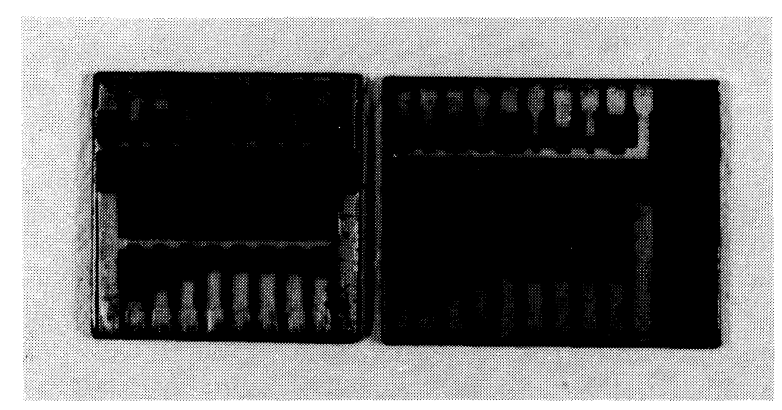

FIGURE 4 Resistor test pattern.

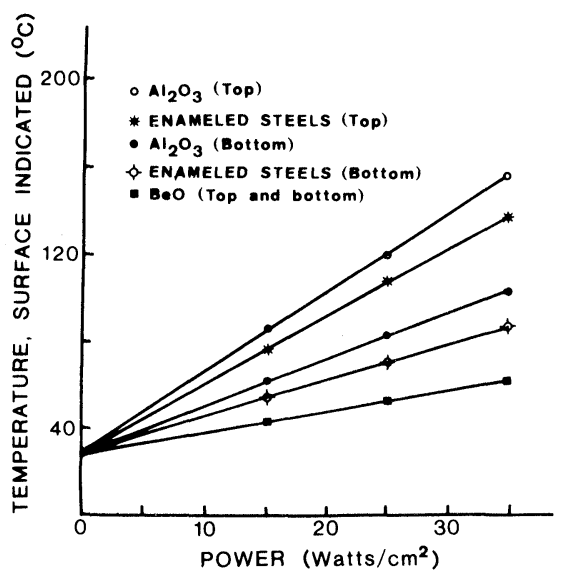

FIGURE 5 Effect of substrate type on the temperature attained under load.

side of substrate immediately below the resistor. The Alphamet ${ }^{\mathrm{TM}}$, Erie 3677 and Erie 3723 substrates had identical results and are plotted on the same lines. Due to the limited number of substrates available, General Electric substrates were not included in this and subsequent tests. Alumina and beryllia (both $0.63 \mathrm{~mm}$ thick) substrate results are shown for comparison. Results ("top" temperatures) show that the heat dissipating characteristics for porcelain enameled steel substrates are better than alumina, but not as good as beryllia when typically used thicknesses of each substrate type are compared. The spread between the "top" and "bottom" temperatures for each substrate is a measure of the effective thermal conductivity of the substrate. The porcelain enamel effective thermal conductivity is slightly higher than that for alumina, but not as high as for beryllia (for which the "top" and "bottom" temperatures are very close and are plotted on the same line). References 3, 9 and 10 discuss somewhat similar results in comparing porcelain enameled steel and ceramic substrates.

\section{PROPERTIES OF THICK FILM RESISTORS ON ENAMELED STEEL SUBSTRATES}

The ESL \#3100 Series of resistors is a ruthenium based system specially designed for use on enameled steel substrates. It is printed to a dried film thickness of 25 microns and is designed to be fired at a peak temperature of $625^{\circ} \mathrm{C}$ for $10-12$ minutes at peak. The approximate heating and cooling rates are $70^{\circ} \mathrm{C} / \mathrm{min}$., and the total cycle time is 45 minutes. 


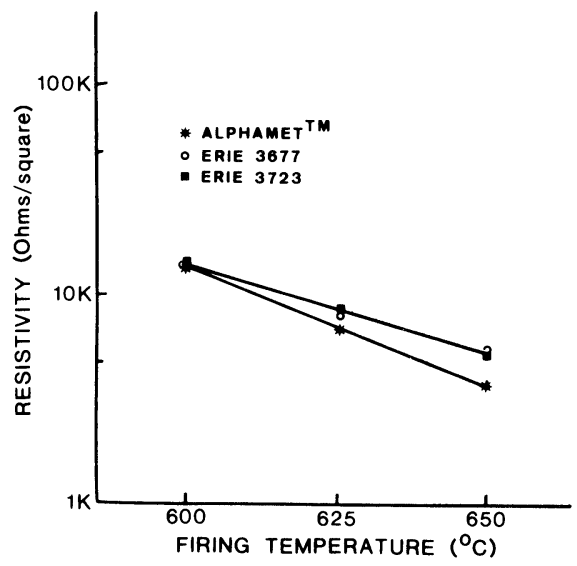

FIGURE 6 Resistivity of ESL \#3114. Pd-Ag terminations, $45 \mathrm{~min}$. firing time, $1.25 \mathrm{~mm} \times 1.25 \mathrm{~mm}$ resistors.

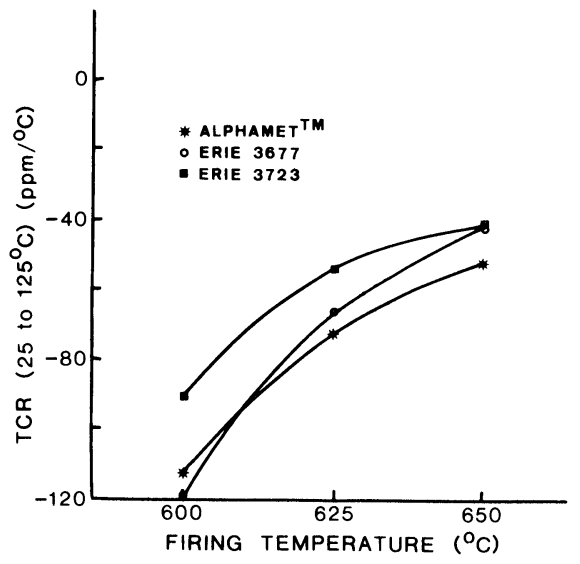

FIGURE 7 TCR of ESL \#3114. Pd-Ag terminations, $45 \mathrm{~min}$. firing time, $1.25 \mathrm{~mm} \times 1.25 \mathrm{~mm}$ resistors.

Resistivity ranges from $10 \mathrm{ohm} / \mathrm{sq}(\# 3111)$ to $1 \mathrm{Mohm} / \mathrm{sq}$ (\#3116) in decade values are available. The standard calibration termination material is ESL \#9694 palladium-silver.

Figures 6 and 7 show the influence of peak firing temperature on the resistivity and TCR of \#3114 $(10 \mathrm{kohm} / \mathrm{sq})$ when Erie 3677, Erie 3723 and Alphamet ${ }^{\mathrm{TM}}$ substrates are used. The two types of Erie substrates give virtually identical results while the Alphamet ${ }^{\mathrm{TM}}$ substrates give slightly lower resistivities. In all cases, higher firing temperatures give lower resistivities.

The TCR of \#3114 is similar on Erie 3677 and Alphamet ${ }^{\text {TM }}$ substrates. Erie 3723 gives slightly less negative TCR's for the 600 and $625^{\circ} \mathrm{C}$ firing

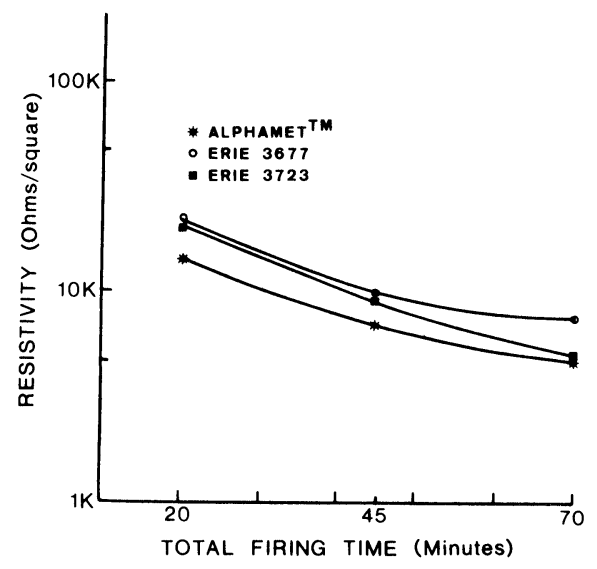

FIGURE 8 Resistivity of ESL \#3114. Pd-Ag terminations, $625^{\circ} \mathrm{C}$ peak firing temperature, $1.25 \times 1.25 \mathrm{~mm}$ resistors.

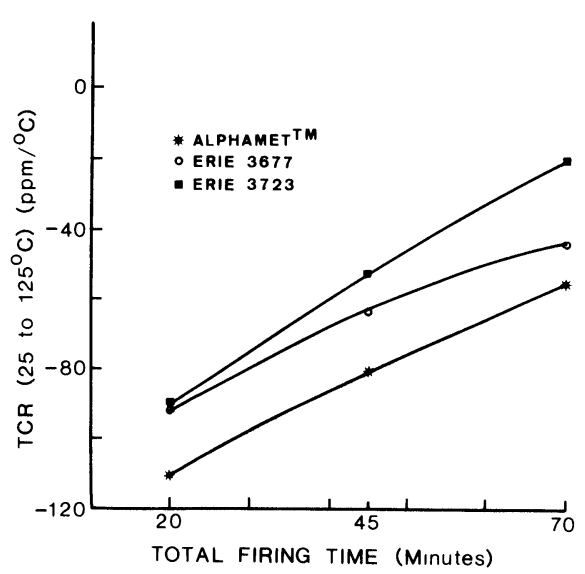

FIGURE 9 TCR of ESL \#3114. Pd-Ag terminations, $625^{\circ} \mathrm{C}$ peak firing temperature, $1.25 \mathrm{~mm} \times 1.25 \mathrm{~mm}$ resistors.

temperatures. TCR's for the $625^{\circ} \mathrm{C}$ calibration temperature are in the -55 to $-70 \mathrm{ppm} /{ }^{\circ} \mathrm{C}$ range for all substrates tested. Lower peak firing temperatures give more negative values while higher firing temperatures shift TCR's towards more positive values.

The effect of total firing time $\left(625^{\circ} \mathrm{C}\right.$ peak $)$ is seen in Figures 8 (resistivity) and 9 (TCR). In all cases, the resistivity decreases with increasing tiring time. The resistivity of \#3114 on the two types of Erie substrates is essentially the same with both 20 and 45 minute cycles; the Erie 3723 gives values approximately $2.5 \mathrm{kohm} / \mathrm{sq}$ below those on Erie 3677 with the 70 minute cycle. Alphamet ${ }^{\text {TM }}$ 
results are approximately 3 to $5 \mathrm{kohm} / \mathrm{sq}$ below the Erie 3677 at all three firing speeds tested.

TCR's all become more positive with longer firing cycles. Differences among the substrate types are approximately $35 \mathrm{ppm} /{ }^{\circ} \mathrm{C}$ maximum, with the Erie 3723 giving the most positive results and the Alphamet ${ }^{\mathrm{TM}}$ the most negative. The resistivity and TCR of \#3114 are not severely affected by these variations in firing temperature or firing cycle duration for any of the three substrates investigated. More detailed information on other compositions of ESL \#3100 resistor system may be found in Ref. 11.

\section{PROPERTIES OF THICK FILM CONDUCTORS ON ENAMELED STEEL SUBSTRATES}

The resistivity of gold, platinum-gold, palladiumsilver, platinum-silver, copper, and silver conductors was measured on a 400 square, $0.25 \mathrm{~mm}$ wide line on Alphamet ${ }^{\mathrm{TM}}$, Erie 3677 and Erie 3723 substrates. Figure 10 illustrates the test pattern used. The gold (ESL \#8835-1B) conductor is 3 to $3.5 \mathrm{mohm} / \mathrm{sq}$, the platinum-gold ( $\# 5836$ ) conductor is 30 to $35 \mathrm{mohm} / \mathrm{sq}$, the palladium-silver (\#9694) and platinum-silver (\#9595A) conductors are 4 to 5 $\mathrm{mohm} / \mathrm{sq}$, the copper (nitrogen fired \#2320) is 3 to $5 \mathrm{mohm} / \mathrm{sq}$, while the silver (\#9996A) conductor is $2 \mathrm{mohm} / \mathrm{sq}$. In all cases, the resistivity observed was not significantly affected by the type of enameled substrate used.

Table III compares wire bonding to a gold thick film conductor on various enameled steel substrates. Three types of wire bonding techniques were investigated: ultrasonic using aluminum ( $1 \%$ silicon) wire, ultrasonic using gold wire, and thermosonic using gold wire. Gold wire is not normally ultrasonically bonded at room temperature, but rather is used in the thermosonic mode at 125 to $150^{\circ} \mathrm{C}$. The room temperature data is presented for informational

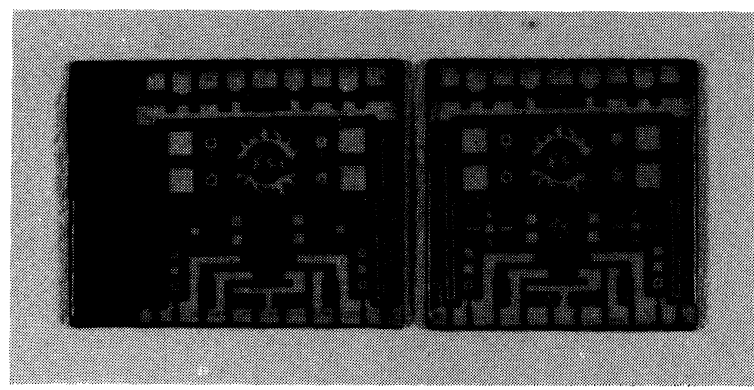

FIGURE 10 Conductor test pattern.
TABLE III

The effect of substrate on wire bond strength. Gold conductor (\#8835-1B) and $25 \mu \mathrm{m}$ wire diameter.

Wire Bond Strength, $\mathrm{g}$

\begin{tabular}{llll}
\hline Substrate & $\begin{array}{l}\text { Ultrasonic } \\
\mathrm{Al}(1 \% \mathrm{Si})\end{array}$ & $\begin{array}{l}\text { Ultrasonic } \\
\mathrm{Au}\left(25^{\circ} \mathrm{C}\right)\end{array}$ & $\begin{array}{l}\text { Thermosonic } \\
\mathrm{Au}\left(125^{\circ} \mathrm{C}\right)\end{array}$ \\
\hline Alphamet $^{\mathrm{TM}}$ & $6-9$ & $3-5$ & $5-8$ \\
Erie 3677 & $9-12$ & $3-5$ & $6-8$ \\
Erie 3723 & $6-10$ & $4-6$ & $6-8$ \\
\hline
\end{tabular}

purposes. The influence of substrate on wire bonding does not appear to be significant.

\section{PROPERTIES OF A THICK FILM DIELECTRIC ON ENAMELED STEEL SUBSTRATE}

A multilayer dielectric M-4030, developed for enameled steel substrate use, was tested on Alphamet ${ }^{\mathrm{TM}}$, Erie 3677 and Erie 3723 substrates using \#9694, palladium-silver terminations. Figure 11 illustrates the test pattern used. No significant differences were noted among the substrates in dielectric constant or dissipation factor. The dielectric constant varied from 14.0 to 15.0 , while the dissipation factor was less than $0.2 \%$ in all cases.

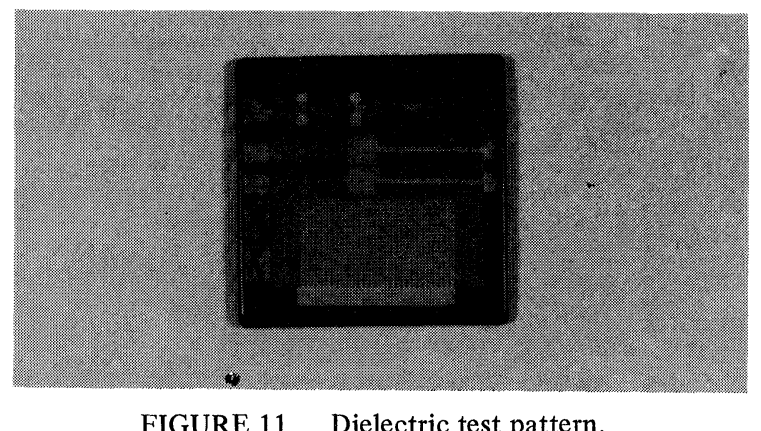

\section{CONCLUSIONS}

The General Electric substrates give superior results in surface and bulk resistivity and voltage breakdown resistance. These substrates also exhibit the lowest dielectric constants measured in this work. New variations of Alphamet ${ }^{\mathrm{TM}}$ substrates are expected to be available in the near future. A new type of 
Erie substrate was received just as this manuscript was completed. All of the substrates tested could be utilized to produce satisfactory thick film circuits. The utility of this technology and its applications can be broadened substantially, as the quality and availability of substrates improve. Continuing changes, improvements and additional sources of supply of substrates are expected to modify some of the observations of this paper and are expected to overcome some of the present shortcomings. This should enhance the use of enameled steel substrates for large area and lower cost applications. ESL \#2320 copper conductor on enameled substrates has shown promise for applications involving replacement of plastic printed wiring boards on an economical basis.

\section{ACKNOWLEDGEMENTS}

The authors wish to thank Gene A. Perschnick for his assistance and Daniel P. Wicher, of the Singer Company, for the enamel thickness measurements.

\section{REFERENCES}

1. A. I. Andrews, Porcelain Enamels, (Garrard Press, Champaign, Ill. 1961).
2. A. Lacchia, Electrostatic Spraying of Powder Enamels, Ceramic Industry (Nov. 1977) 36-7, (Feb. 1978) 26, (Mar. 1978) 35.

3. D. P. Wicher, and W. B. Hatfield, Porcelain Steel Technology: A Bonafide Alternative?, Proc. 1978 Int. Microelectronics Symp., ISHM, Minneapolis MN (1978) $176-187$.

4. Materials Engineering, Vol. 78, No. 4 (Mid-September, 1973).

5. Al Si Mag Ceramics, Chart No. 711, 3M Co, Chattanooga, Tenn.

6. W. B. Hatfield and D. P. Wicher, A Microelectronics Packaging Techn. for Consumer Product Applications, Proc. 1978 Electronic Components Conf., IEEE, Anaheim, CA (1978) 271-276.

7. T. R. Allington and R. E. Cote, Characterization of Thick-Film Compositions on Porcelainized Steel Substrates, Proc. 1978 Int. Microelectronics Symp, ISHM, Minneapolis, MN (1978) 188-192.

8. J. E. Cox, Ion Migration in Porcelain Enamel Coatings, Amer. Cer. Soc. 31st Pacific Coast Regional Meeting, Oct. 1978, available from Alpha Advanced Technology, Inc., Newark, N.J.

9. M. Spector, A New Metal Core Hybrid Substrate, Proc. 1978 Int. Microelectronics Symp. ISHM, Minneapolis, MN (1978) 193-195.

10. M. Spector, Porcelain Coated Steel Substrates for High Density Component Interconnection, Insulation/Circuits (Jan. 1979) 15-17.

11. S. J. Stein, C. Huang and A. S. Gelb, Thick Film Materials on Porcelain Enameled Steel Substrates, Proc. 1979 Electronic Comp. Conf., IEEE, Cherry Hill, N.J. (1979). 

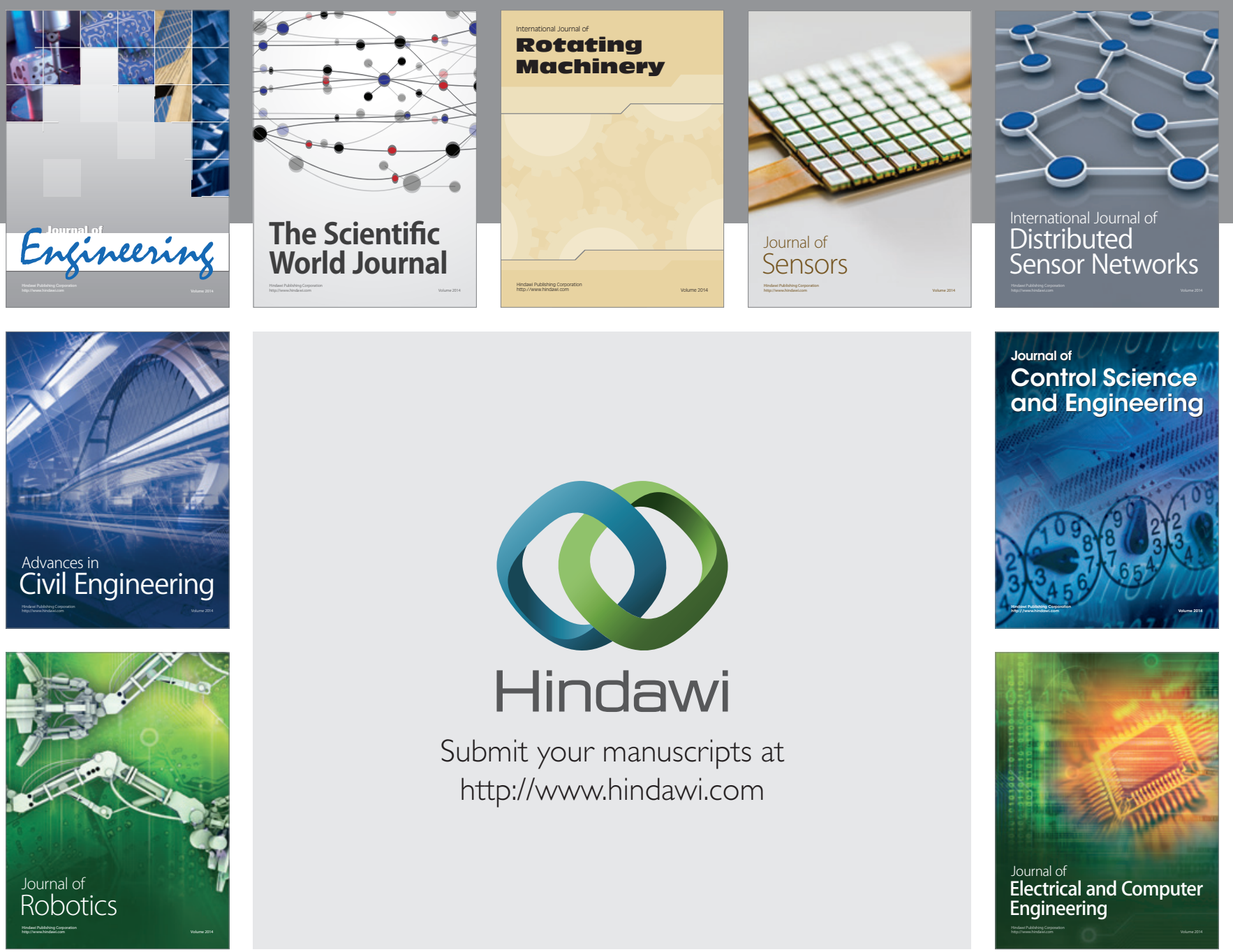

Submit your manuscripts at

http://www.hindawi.com
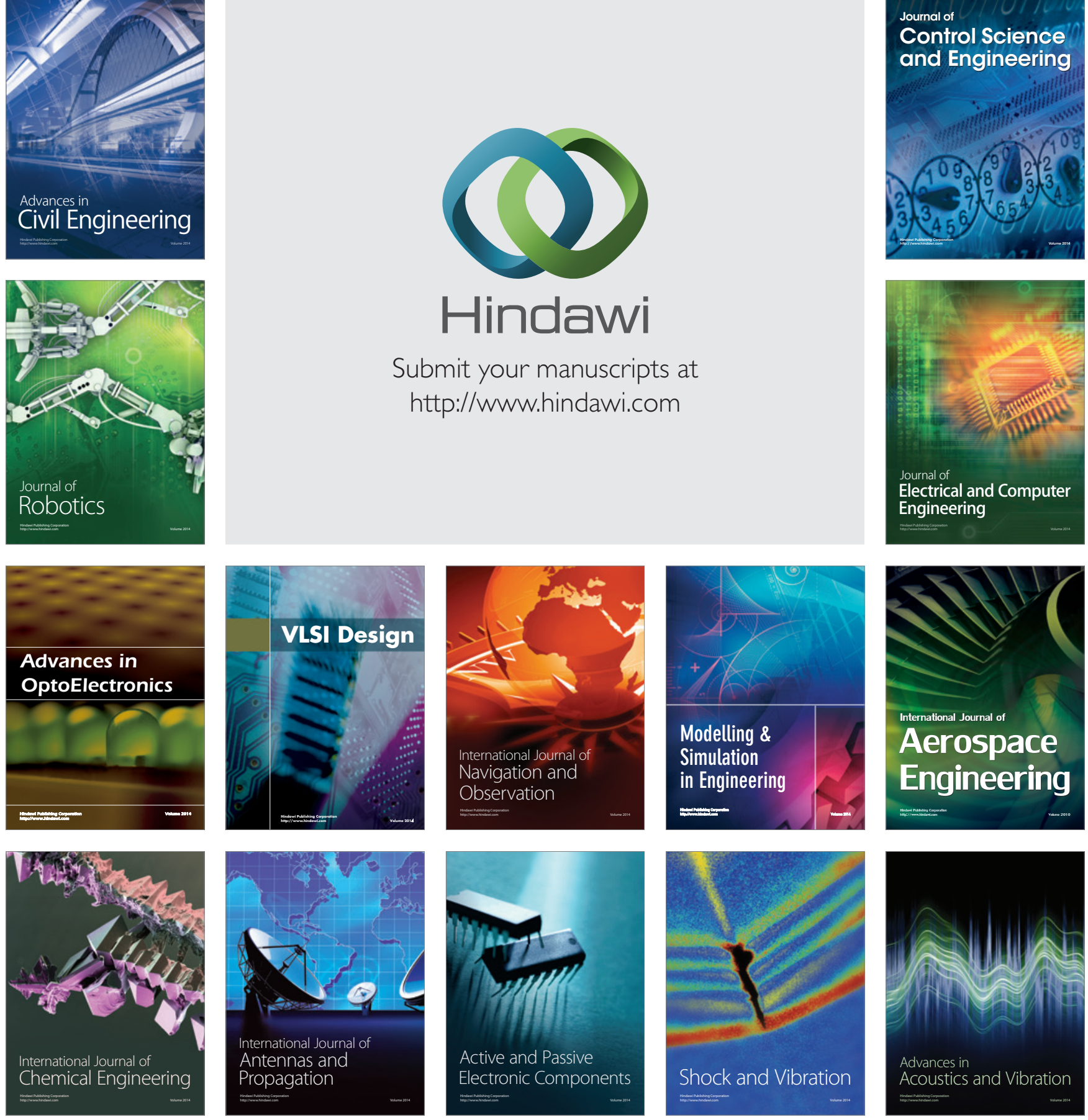